\title{
Modulation of human melanoma cell proliferation and apoptosis by hydatid cyst fluid of Echinococcus granulosus [Corrigendum]
}

Gao XY, Zhang GH, Huang L. Onco Targets Ther. 2018;11:

1447-1456.

On page 1447, the correspondence authors details were incorrectly listed. The correct details are:

Correspondence: Li Huang

Department of General Surgery, Shanghai General Hospital, No 100, Haining Road, Shanghai 200080, China

Tel/fax +8621632400903136

Email anorlee@163.com

OncoTargets and Therapy is an international, peer-reviewed, open access journal focusing on the pathological basis of all cancers, potential targets for therapy and treatment protocols employed to improve the management of cancer patients. The journal also focuses on the impact

of management programs and new therapeutic agents and protocols on patient perspectives such as quality of life, adherence and satisfaction. The manuscript management system is completely online and includes a very quick and fair peer-review system, which is all easy to use. Visit http://www.dovepress.com/testimonials.php to read real quotes from published authors. 